\title{
Hypericum perforatum incorporated chitosan films as potential bioactive wound dressing material
}

\author{
Seda Güneş ${ }^{a}$, Funda Tıhmınlıoğlu ${ }^{\mathrm{b}, *}$ \\ a Graduate Program of Biogineering, Izmir Institute of Technology, Izmir, 35430, Turkey \\ ${ }^{\mathrm{b}}$ Department of Chemical Engineering, Izmir Institute of Technology, İmir, 35430, Turkey,
}

\section{A R T I C L E I N F O}

\section{Article history:}

Received 24 October 2016

Received in revised form 21 April 2017

Accepted 22 April 2017

Available online 24 April 2017

\section{Keywords:}

Chitosan

H. perforatum

Wound dressing

Antimicrobial activity

Cell attachment

\begin{abstract}
A B S T R A C T
Recent studies in wound dressing applications offer new therapies and promote wound healing process. The aim of this study was to develop Hypericum perforatum (St John's Wort) oil incorporated chitosan films for wound dressing applications. H. perforatum oil as a potential therapeutic agent was encapsulated in chitosan film to achieve a better wound dressing material. Oil incorporated chitosan films were successfully prepared by solvent casting method in different oil concentrations $(0.25-1.5 \% \mathrm{v} / \mathrm{v})$. Water vapor permeability (WVP), mechanical test, swelling behavior and surface hydrophobicity were performed in order to characterize the prepared films. Antimicrobial test was performed by disc diffusion method and the growth inhibition effects of the films including different amount of $H$. perforatum oil were investigated on Escherichia coli and Staphylococcus aureus. WVP increased with oil incorporation and the highest value was obtained for $0.25 \%$ oil concentration.The highest strain value was obtained in $0.25 \%$ oil content films although tensile stress decreased with increasing oil content. $H$. perforatum oil incorporated films had antimicrobial effect on both microorganisms. Chitosan based films had no cytotoxic effects on NIH3T3fibroblast cells and provided a good surface for cell attachment and proliferation. The results showed that the $H$. perforatum incorporated chitosan films seems to be a potential and novel biomaterial for wound healing applications.
\end{abstract}

(c) 2017 Elsevier B.V. All rights reserved.

\section{Introduction}

Wound healing is a complex process involving different stages:haemostasis, inflammation, proliferation and maturation and/or remodeling [1,2]. Wound can be classified as acute or chronic wound depend on repair process. In recent years, number of wound dressing materials have been developed to promote healing proces. Many wound dressing materials are applied for different wound types and targeting the different stages of wound healing process [3]. An ideal wound dressing properties should maintain a moist environment at wound/dressing interface, allow gaseous exchange/water vapor, oxygen), have adequate mechanical properties, provide a barrier to microorganisms and remove excess exudutes and toxic components from wound surface. Also it should be non-toxic, non-allergic, easily removable economic without any trauma $[2,4,5]$. Different forms and wound dressing materials such as hydrogels, transparent films, polyurethane foams which are designed for the treatment of both acute and

\footnotetext{
* Corresponding author.

E-mail address: fundatihminlioglu@iyte.edu.tr (F. Tıhmınlıoğlu).
}

chronic wounds. Synthetic (polyurethane) and natural (gelatin, carboxymethylcellulose, chitosan, alginate) polymers could be used as wound dressing material. However, natural biomaterials are more preferable because of easily processing, antimicrobial properties and promoting wound healing with cell proliferation. Among biological dressing materials, chitosan which is FDA approved biopolymer, takes attention due to its biocompatibility, biodegradable, hydrating effect, antiinflammatory, antimicrobial and wound healing properties. Chitosan serves as matrix and supports 3D tissue growth by stimulating cell proliferation. Besides, chitosan is a good hemostat and blocks nerve endings to reduce pain [4]. It has been also shown that chitosan promotes burn healing with the help of proliferation and activation of inflammatory cells in granulation tissue and thus accelerates rapid dermal regeneration and re-epithelization. In addition, chitosan has bacteriostatic effect which prevent the wound area from infection $[5,6]$. Therefore, it was found to be potent material for future wound dressings. Chitosan based wound dressings could be processed in different forms such as hydrogels, film, scaffold etc. Different commercial chitin/chitosan based wound dressing materials are available in the market $[1,4]$. Topical application of chitosan films containing 
growth factor resulted improved healing rate, reduced wound area and promoted granulation tissue formation [7].

Recently, incorporation of therapeutic agents into bioactive wound dressing materials and their controlled release in wound area is a novel approach to control the inflammation, prevent infections as well as stimulation tissue regeneration [8]. A few studies has been reported regarding to development of natural materials with therapeutic properties containing aloe vera extract and some essential oils in alginate $[8,9]$ and polycaprolactone [10] based wound dressings.

In recent years, the use of $H$. perforatum and its derivatives has growing interest and becomes one of the most consumed medicinal plants in the world. H. perforatum is an important medicinal plant with a wide range of therapeutic effects such as depression, anxiety, antiinflammatory, antimicrobial, antioxidant agent, wound healing and pain relief effects $[11,12]$. $H$. perforatum has been studied for pharmaceutical applications due to its components such as hpericins, hyperforins and flavonoids. Hyperforin is the main antibacterial component of Hypericum that improves the ephitelization of skin [13]. Therefore, essential oil of $H$. perforatum takes attention due to its wound healing property and $H$. perforatum has been widely used in Turkish folk medicine for rapid recovery of different kind of wounds and burns during healing. Also it was reported that the one of the most effective and widely spread pharmaceutical application of H. perforatum is wound therapy [13]. Although $H$. perforatum oil is being used in traditional medicine, literature and clinical research on wound treatment application of $H$. perforatum oil as ointment are very limited [14,15]. For the best knowledge, the present study is significant due to encapsulation of $H$. perforatum into polymer and evaluation of wound dressing potential with the synergistic effect of chitosan and $H$. perforatum for the first time. The aim of this study was to develop $H$. perforatum oil incorporated chitosan films as a novel wound dressing material and evaluate its physicochemical properties and biocompatibility. In this study, the effects of four different concentrations of $H$. perforatum oil were investigated on the antimicrobial, mechanical and physicochemical properties of chitosan films. In vitro cell attachment and proliferation of NIH3T3 cells on oil loaded chitosan films were evaluated to promote wound healing.

\section{Materials and methods}

\subsection{Materials}

Chitosan (low molecular weight, degree of deacetylation $85 \%$ ) was purchased from Sigma. Hypericum perforatum oil (Alvin,Turkey) was purchased from local pharmacy. Acetic acid and ethanol (Merck, Germany) were used as solvents. WST-1 was purchased from Biovision (USA) for cytotoxicity assay. Dulbecco's Modified Eagle Medium (DMEM), fetal bovine serum (FBS), phosphate-buffered saline (PBS), Penicillin-streptomycin antibiotic solution were purchased from Gibco (USA). DAPI (4', 6-diamidino-2-phenylindole, dihydrochloride) (Cell Signaling, USA) and Alexa Four 488 Phalloidin (Molecular Probes ${ }^{\mathrm{TM}}$,Thermo Fisher Scientific) stains were used for fluorescence imaging. 37\% paraformaldehyde (Merck, Germany) was used for fixation of cells.

\subsection{Preparation of $\mathrm{H}$. perforatum incorporated chitosan films}

Both chitosan and chitosan/H. perforatum films were prepared using solvent casting method. Chitosan film forming solution (FFS) $(1 \% \mathrm{w} / \mathrm{v})$ was prepared by dissolving $0.5 \mathrm{~g}$ low molecular weight chitosan in $50 \mathrm{ml}$ of $1 \mathrm{wt} \%$ acetic acid solution under magnetic stirring and left overnight for completely dissolution. Tween 80 was added at a percentage of $0.1 \%(\mathrm{v} / \mathrm{w})$, based on the polymer weight as an emulsifier to improve solubility of oil. Different concentrations of $H$. perforatum $(0.25,0.5,1,1.5 \% \mathrm{v} / \mathrm{v}$ based on FFS) were added dropwise into chitosan solution under magnetic stirring. Film forming solution was sonicated for $15 \mathrm{~min}$ for homogenization and left to degasification for $5 \mathrm{~min}$ by ultrasonic bath. The prepared solutions were casted onto polystyrene petri dishes and dried for room temperature for $24 \mathrm{~h}$. Finally films were vacuum dried at $25^{\circ} \mathrm{C}$ for $24 \mathrm{~h}$. The dry films were peeled off and stored at desiccator for analysis.

\subsection{Characterization of films}

\subsubsection{Scanning electron microscopy (SEM)}

Surface morphology of films were examined by Scanning Electron Microscopy (SEM, Quanta) in Centre for Materials Research in İzmir Institute of Technology, İzmir. For SEM analysis, the cross-sections of samples were mounted on metal grids using double-sided adhesive tape and coated with gold layer under argon gas by using Emitech K550X.

\subsubsection{Determination of film thickness and film appearance}

The film thickness was measured using a hand-held electronic digital micrometer (Mitutoyo) with $1 \mu \mathrm{m}$ sensitivity. Each film sample was measured at different five positions along the strip; an average value is reported. The mechanical properties (tensile strength and percent elongation) and water vapor permeability (WVP) were calculated using the average thickness of each film sample.

The color of the chitosan film samples was determined using Chroma meter (Avantes, USA). Measurements were expressed as L, $\mathrm{a}$ and $\mathrm{b}$, these values are L black $(-)$ to white $(+)$, a green $(-)$ to red $(+)$, and b blue $(-)$ to yellow $(+)$. Each film sample was measured at its center and three different positions. Total color difference $(\Delta \mathrm{E})$ was calculated as follows:

$\Delta E=\left(\Delta L^{2}+\Delta a^{2}+\Delta b^{2}\right)^{0.5}$

\subsubsection{Mechanical test}

Mechanical properties of chitosan films were determined according to ASTM D882-95 standart by tensile tests. Films were cut into rectangular specimens $(1 \times 5 \mathrm{~cm})$ and conditioned $23^{\circ} \mathrm{C}$ and at $50 \% \mathrm{RH}$ for $24 \mathrm{~h}$. Thickness of chitosan films was measured with an electronic digital micrometer (293-821. Mitutoyo). Mechanical properties, including Elastic Modulus, tensile strength (TS) and elongation at break $(\epsilon)$, were measured using a TA.XTplus Texture Analyser (Stable Micro Systems, UK), with a $5 \mathrm{~kg}$ load cell equipped with tensile grips at a crosshead speed of $10 \mathrm{~mm} \mathrm{~min}^{-1}$. Grip separation was set to $50 \mathrm{~mm}$. TS was expressed in MPa and calculated by dividing the maximum load by initial cross-sectional area of film. \% elongation at break, \% $\epsilon$, was calculated as the ratio of final length to initial length of film and expressed as a percentage. Elastic Modulus, E, was calculated from the slope of stress-strain linear region. At least five measurements were performed for each type of film.

$$
\begin{aligned}
& \% \varepsilon=\frac{\Delta l}{l_{0}} \\
& E=\frac{T S}{\% \varepsilon}
\end{aligned}
$$

\subsubsection{Water vapor permeability (WVP)}

The water vapor permeability of the films (WVP) was determined according to ASTM E96 standards by using the apparatus which consist of two chambers separated with a test film sample. WVP values of the films were compared with the skin values. The films with $4 \mathrm{~cm}$ diameter were cut and placed between two compartments. The measurements were taken by computer. The 

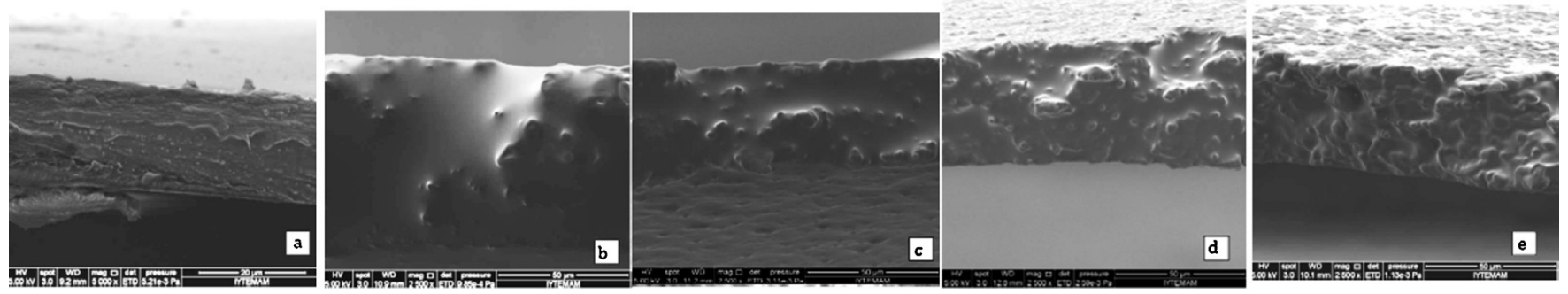

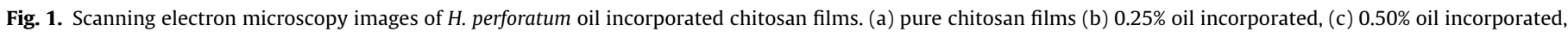
(d) $1 \%$ oil incorporated, (e) $1.5 \%$ oil incorporated chitosan films.

upper chamber includes a humidity probe which is connected to a Datalogger SK-L 200 TH to monitor relative humidity (RH) and temperature versus time. The lower chamber was filled with deionized water to maintain $100 \% \mathrm{RH}$ and upper chamber was maintained $5 \%$ RH with dry air at room temperature. Water vapor permeability was calculated using the Ficks Diffusion assuming that transport is one dimensional. The integrated form of the flux equation (Eq. (4)) can be used to calculate the permeability coefficient [5] using experimentally collected relative humidity versus time data.

$\ln \frac{P_{1 L}-P_{1 u i}}{P_{1 L}-P_{1 u(t)}}=\frac{P_{e f f} * A R T}{V * L} t$

$\mathrm{P}_{\text {eff }}$ can be calculated from $\ln \left[\left(\mathrm{P}_{\mathrm{IL}}-\mathrm{P}_{1 \mathrm{ui}}\right) /\left(\mathrm{P}_{\mathrm{IL}}-\mathrm{P}_{1 \mathrm{ut}}\right)\right]$ vs time graph. $\mathrm{P}_{1 \mathrm{~L}}$ and $\mathrm{P}_{1 \mathrm{u}}$ are partial pressure in the lower and upper compartments, respectively. $A$ is the transfer area of the exposed film surface $\left(\mathrm{m}^{2}\right), t$ is test tme, $\mathrm{R}$ is the gas constant, $\mathrm{V}$ is the volume of the chamber. WVP of the films was calculated in the units of $\mathrm{mol} / \mathrm{min} \mathrm{cm} \mathrm{kPa}$. Water vapor transmission rates (WVTR) of the films were also calculated as $\mathrm{g} / \mathrm{m}^{2}$ day.

\subsubsection{Swelling properties}

The swelling degree (\% SD) of chitosan films was determined in $\mathrm{PBS}$ at $37^{\circ} \mathrm{C}$. At equilibrium swelling time, the films were weighted after removing the excess water from the surface of the films with filter paper. The swelling degree (\%SD) of the films was calculated using the equation:

$\% S D=\frac{\left(W-W_{0}\right)}{W_{0}} * 100$

where $\mathrm{W}$ represents the weight of the wet films absorbing water and $W_{0}$ is the weight of the dry films before swelling. The results were given as mean $\mathrm{SD} \pm$ standart deviation.

\subsubsection{Contact angle}

Surface wettability is an important parameter that affects several properties of the biomaterials, such as the water absorption, bioadhesion and cell interaction. The surface hydrophobicity or wettability of $H$. perforatum incorparated chitosan films were evaluated by contact angle measurements. Contact angle measurements were carried out with sessile drop method. A $6 \mu$ l droplet of PBS was gently dropped on the film surface. For each sample, five measurements were performed using KSC-Attension Theta Optical Tensiometer and the average values were reported.

\subsection{Antimicrobial activity of film forming solution (FFS)}

Antimicrobial activities of film forming solutions containing different concentrations of $H$. perforatum essential oil were determined by agar diffusion method on strains of E.coli and Staphylococcus aureus. The frozen stocks were activated at $37^{\circ} \mathrm{C}$ for overnight. Cultured microorganisms were suspended in $2.5 \mathrm{ml}$ phosphate-buffered saline (PBS) solution and turbidity was adjusted to McFarland 0.5. Then, the inoculum was spread on the
Mueller-Hinton agar plates. The empty discs with $14 \mathrm{~mm}$ diameter were placed on the inoculated agar. Approximately $20 \mu \mathrm{l}$ of film forming solutions (FFS) of chitosan and $H$. perforatum oil/chitosan were dropped onto empty dics. Then, plates were incubated at $37^{\circ} \mathrm{C}$ for $24 \mathrm{~h}$ in the incubation chamber. At the end of the incubation period, the clear zones around the discs were measured and recorded as inhibition zone that indicates antimicrobial property.The measurements were performed in twice.

\subsection{In vitro cell viability assay}

In vitro cell viability of chitosan films was evaluated by the WST-1 assay on NIH3T3 mouse fibroblasts cell lines according to ISO 10993-5 indirect extraction method. Working principle of WST-1 [4-3-(4-Iodophenyl)-2-(4-Nitrophenyl)-2H-5-Tetrazolio]1,3 -Benzene Disulfonate] assay is based on the conversion of stable tetrazolium to a soluble formazan by a complex cellular mechanism that occurs primarily at the cell surface. This bioreduction is largely dependent on the glycolytic production of $\mathrm{NAD}(\mathrm{P}) \mathrm{H}$ in viable cells. Cells were maintained in DMEM supplemented with $2 \mathrm{mM} \mathrm{L-}$ glutamine, $10 \%$ fetal bovine serum, $100 \mu \mathrm{g} / \mathrm{ml}$ streptomycin and $100 \mathrm{U} / \mathrm{ml}$ penicillin in an atmosphere of $5 \% \mathrm{CO}_{2}$ at $37^{\circ} \mathrm{C}$. Briefly, cells were seeded in 96 well-plate at the density of $1^{*} 10^{4}$ cell/well and incubated overnight at $37^{\circ} \mathrm{C}$ in an atmosphere of $5 \% \mathrm{CO}_{2}$. Then, the medium containing extract $(100 \mu \mathrm{l})$ was added to the seeded cells and incubated for $24 \mathrm{~h}, 48 \mathrm{~h}$ and $72 \mathrm{~h}$. Cell viability was determined by using the WST- 1 assay. At the end of the incubation time, medium was removed and medium containing $10 \%$ WST-1 (Biochemica) was added. After incubation at $37^{\circ} \mathrm{C}$ for $3 \mathrm{~h}$ in darkness, absorbance was determined by using microplate reader (Varioscan Spectrophotometers, Thermo) at $490 \mathrm{~nm}$ and the cell viability was calculated using Eq. (6) by dividing absorbance of well plate containing extract with absorbance of the control well plate. Experiments were performed in triplicate and data was represented as mean \pm standard deviation (SD).

$\%$ Viability $=\frac{\text { Optical density (OD) of treated cells }}{\text { OD of control cells }} * 100$

\subsection{In vitro cell proliferation and cell attachment}

In vitro cell attachment and proliferation on prepared films were evaluated using DAPI-phalloidin staining and WST-1 cell proliferation assay $(n=3)$. NIH3T3 cells were grown in DMEM containing $10 \%$ fetal bovine serum, 100 units/ml penicillin and $100 \mu \mathrm{g} / \mathrm{ml}$ streptomycin. The cells were maintained in $5 \% \mathrm{CO}_{2}$ incubator at $37^{\circ} \mathrm{C}$. The cells were seeded on films at a concentration of $5^{*} 10^{4}$ cells $/ \mathrm{mL}$ placed on 24 well plate and incubated for 1,3 and 7 days. At the end of the incubation period, WST1 was added to determine NIH3T3 growth on the chitosan films and incubated for $2 \mathrm{~h}$ in darkness. After incubation, absorbance was determined by using the microplate reader (Varioscan Spectrophotometers, Thermo) at $490 \mathrm{~nm}$. Experiments were performed 


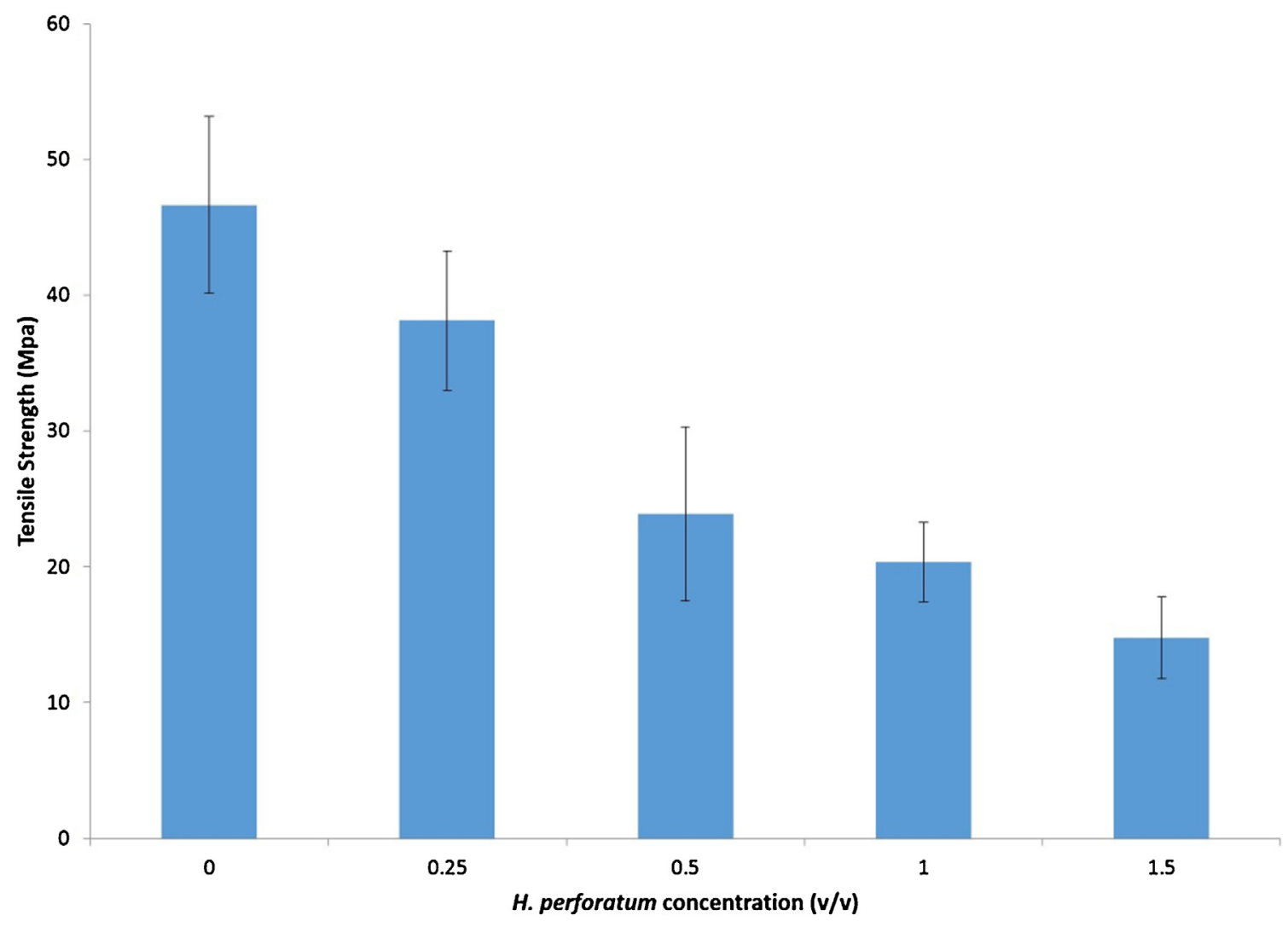

Fig. 2. Tensile stress of pure chitosan and oil incorporated chitosan films.

in triplicate $(n=3)$. Data was represented as mean \pm standard deviation (SD).

Cell attachment on chitosan films was determined by fluorescence microscopy and attached cells were observed by SEM analysis. After incubation, the cells on films were fixed with $3.7 \%$ paraformaldehyde ( $\mathrm{w} / \mathrm{v}$ in PBS) solution for $20 \mathrm{~min}$, washed in PBS and permeabilized with $0.1 \%$ Triton $\mathrm{X}-100$ for $5 \mathrm{~min}$. The samples were rinsed with PBS again and stained with Phalloidin (Alexa Fluor) and DAPI to stain F-actin and nucleus. Then, fluorescently labelled cells were examined by using fluorescence microscope (Zeiss, Axio).

The fixed cells on the surfaces were also dehydrated in ethanol graded series (50\%, 70\%, 80\%, 90\% and $100 \%$ ) for 5 min. The samples were mounted on stubs and coated in vacuum with gold to examine SEM.

\section{Result and discussions}

\subsection{Surface morphology}

Surface morphology and cross-sectional area of films were investigated by SEM analysis. The micrograph clearly showed that the pure chitosan matrix had relatively smooth surface (Fig. 1). Pure chitosan films were transparent and colorless. The incorporation of Hypericum oil increased roughness and opaqueness of the films. The oil droplet size and the number of droplets also increased with increase of Hypericum oil concentration (Fig. 1). The SEM images of the films indicate that an increase in Hypericum oil concentration resulted in more porous structure in which pores were distributed homogeneously. It was observed that oil droplets in the film structure were homogenously distributed across the film. Similar findings were reported in our earlier study [5] for thyme
Table 1

Effect of essential oil on physical properties of the chitosan films.

\begin{tabular}{lcc}
\hline $\begin{array}{l}\text { Oil concentration } \\
\%(\mathrm{v} / \mathrm{v})\end{array}$ & Film thickness $(\mathrm{mm})$ & $\Delta E$ \\
\hline 0 & $0.033 \pm 0.0018$ & $9.09 \pm 0.46$ \\
0.25 & $0.043 \pm 0.0012$ & $6.88 \pm 0.49$ \\
0.5 & $0.05 \pm 0.0016$ & $7.25 \pm 0.43$ \\
1 & $0.052 \pm 0.0019$ & $7.36 \pm 0.52$ \\
1.5 & $0.066 \pm 0.0029$ & $8.42 \pm 1.36$ \\
\hline
\end{tabular}

oil and [16] study for lemon, thyme and cinnamon oil incorporated chitosan films.

\subsection{Physical appearance}

The physical properties of chitosan films with $H$. perforatum incorporation were shown in Table 1 . The average thickness of the control and $H$. perforatum oil incorporated films was changed in the range of $0.033-0.066 \mathrm{~mm}$. The thickness of the prepared films were listed in Table 1. It was clearly seen that film thickness increased with increased oil concentration. From ANOVA test, the differences between the groups was significant $(p<0.05)$.

The incorporation of Hypericum oil did not affect much the appearance of edible films (Table 1$)$. The total color difference $(\Delta \mathrm{E})$ was slightly decreased when $H$. perforatum oil was incorporated.

\subsection{Mechanical properties}

Mechanical properties of the films were evaluated in terms of tensile strength, \% strain and Young's modulus values which are related to structural characteristic of the films. Tensile strength of the prepared films which means the maximum stress of a film during tensile testing, is shown in Fig. 2 as a function of oil loading. As 


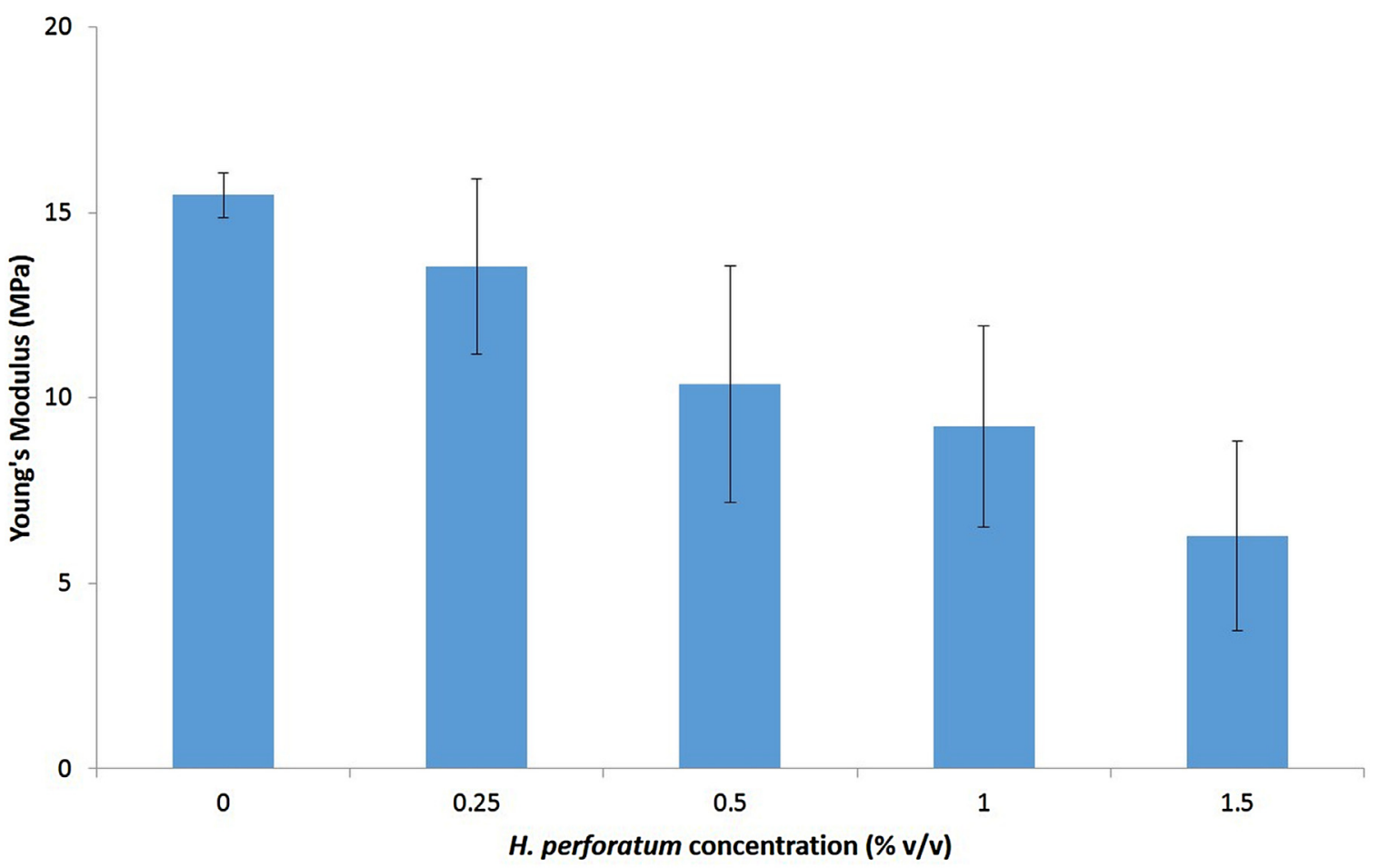

Fig. 3. Young's Modulus of pure chitosan and oil incorporated chitosan films.

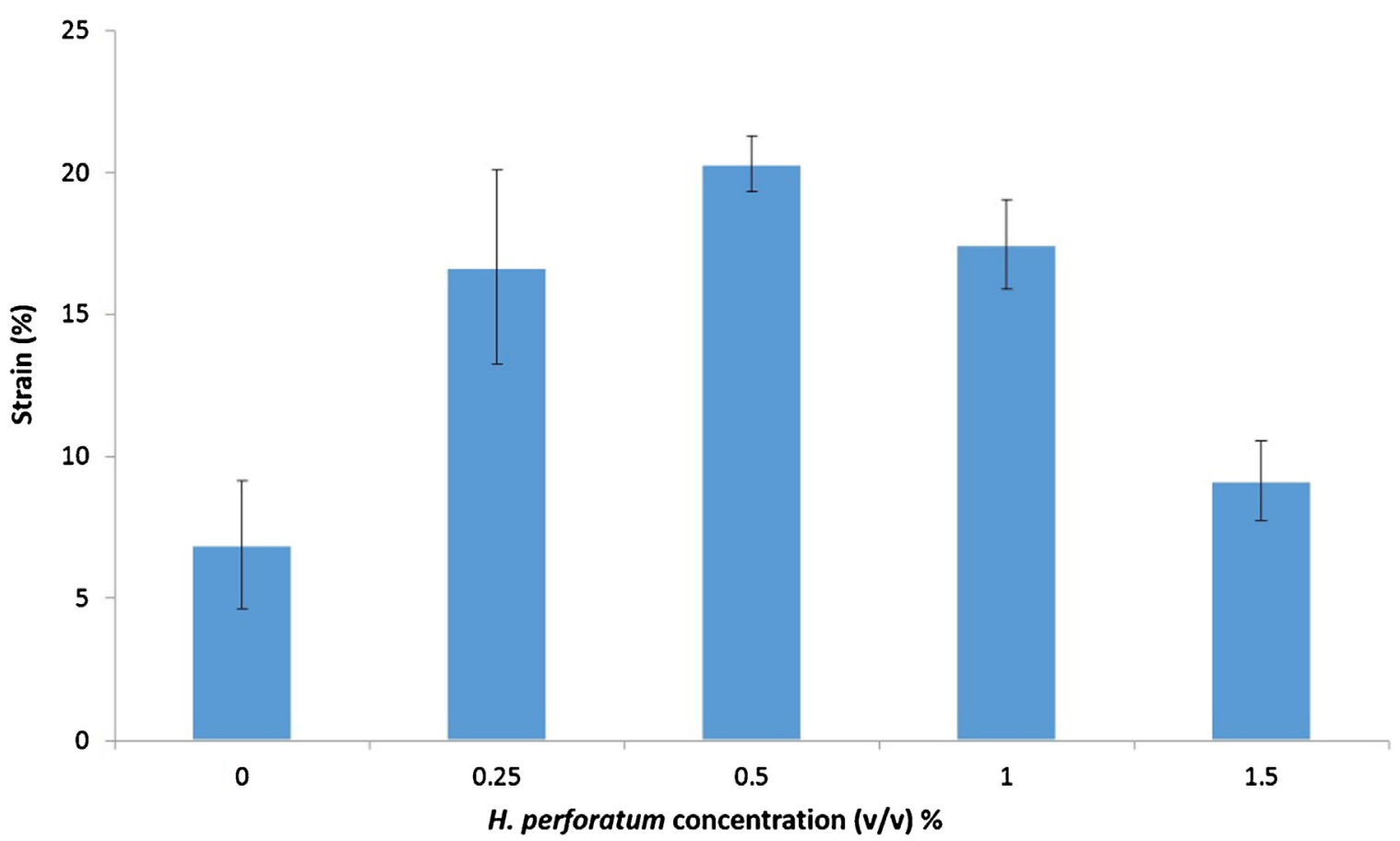

Fig. 4. Strain (\%) values of pure chitosan and oil incorporated chitosan films.

seen in Fig. 2, H. perforatum oil incorporation into chitosan matrix reduced $68 \%$ of the tensile strength to of the films from $44.6 \mathrm{MPa}$ to 14.8 MPa for $1.5 \%(\mathrm{v} / \mathrm{v})$ of EO incorporation.This result was in good agreement with related studies which are conducted by [5,17-19]. In general, incorporation of an additive other than crosslinking agents generally reduces TS value [20]. However, Abdollahi et al. found that the TS of chitosan/clay based nanocomposite improved by incorporation of low amount of rosemary oil (REO) [21]. Young's modulus of the prepared films in this study (E) also reduced by the incorporation of $H$. perforatum oil (Fig. 3). Generally, mechanical properties are related with film network microstructure and intermolecular forces [16]. Strain is elongation at break which is a measure of the film's stretch ability prior to breakage. Incorporation of oil increased \% elongation value than that of control chitosan films at low concentration of $H$. perforatum oil as seen in Fig. 4. Strain increased with increasing oil content except $1.5 \%$ oil concentration. The \% elongation of the prepared films increased from $6.9 \%$ (control) to $20.4 \%$ for the films containing $0.5 \%(\mathrm{w} / \mathrm{v}$ ) oil. Although 


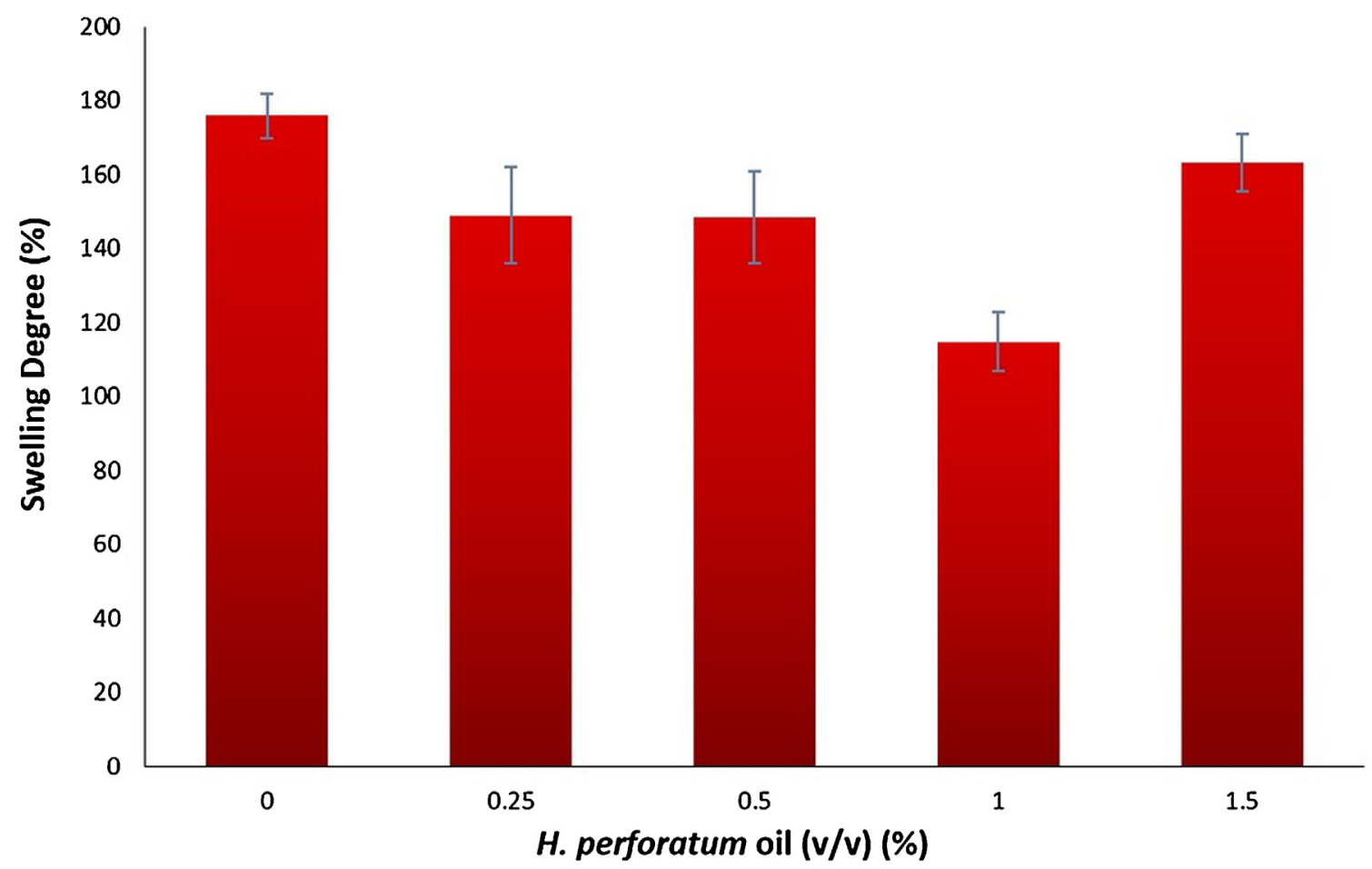

Fig. 5. Swelling degree of pure and oil incorporated chitosan films.

strain value of film was decreased to $17.5 \%$ and $9 \%$ for $1 \%$ and 1.5 oil incorporated films, strain value was still higher than control chitosan films. Oil incorporation generally acts as plasticizer and therefore, the incorporation of $H$. perforatum oil resulted in a film matrix that was less rigid and promoted the motion of the polymer chains and enhanced the film flexibility. This situation could be explained by the replacement of polymers with the oil droplets in the film matrix. Inclusion of oils in polysaccharide-based films can interfere with polymer chain-to-chain interactions and produce flexible domains within the film due to the more dominant interaction between polar polymer molecules those between polar polymer and non-polar lipid molecules [21]. As found similarly in the study of Abdollahi et al. the strain \% increased significantly by incorporating rosemary oil (REO) up to $44 \%$ and indicated that REO has shown a plasticizing ability. It can be explained as the presence of essential oil in low amounts changes the hydrogen-bonding network within the material [22].

\subsection{Water vapor permeability (WVP)}

WVP is an important property in wound dressing because, it is very crucial to control the water loss from wound and to maintain a moist environment during the wound-repairing process. To determine the WVP properties of the prepared films, water vapor permeation test was performed. Permeabilities of prepared films were calculated using Eq. (4). The water vapor permeabilities of the oil incorporated chitosan films were demonstrated in Table 2. As seen in Table 2, the water vapor permeability of chitosan film was slightly increased by incorporating Hypericum perforatum oil to the films. $0.25 \%$ and $0.50 \%$ oil incorporated films were found to be more permeable than the other films. This behavior could be explained by the formation of porous structure with the addition of oil into chitosan matrix as supported by SEM data. Our results were in good aggrement with the study of Altiok et al. [5].

In this study, the water vapor transmission rate (WVTR) of control and $H$. perforatum oil incorporated chitosan films was also
Table 2

Water vapor permeability and water vapor transmission rate of Hypericum perforatum oil incorporated chitosan films.

\begin{tabular}{lcc}
\hline $\begin{array}{l}\text { Oil concentration } \\
\%(\mathrm{v} / \mathrm{v})\end{array}$ & $\begin{array}{l}\text { WVPx } 10^{7} \\
(\mathrm{~mol} / \mathrm{kPa} \text { min } \mathrm{cm})\end{array}$ & $\begin{array}{l}\text { WVTR } \\
\left(\mathrm{g} / \mathrm{m}^{2} \text { day }\right)\end{array}$ \\
\hline 0 & 3.76 & 292.4 \\
0.25 & 6.28 & 487.5 \\
0.5 & 5.52 & 429.2 \\
1 & 4.32 & 332.0 \\
1.5 & 4.17 & 364.7 \\
\hline
\end{tabular}

determined (Table 2). An ideal dressing would control the evaporative water loss from a wound at an optimal rate. The rate for normal skin is reported as $204 \mathrm{~g} / \mathrm{m}^{2}$ per day, while that for injured skin is $279 \mathrm{~g} / \mathrm{m}^{2}$ per day for a first-degree burns [23]. The water vapor permeability of a wound dressing should prevent both excessive dehydration as well as build up of exudate and water vapor transmission rate was reported in the literature with broad range of $76-9360 \mathrm{~g} / \mathrm{m}^{2}$ day depending on the material used for wound healing applications $[24,25]$. Therefore, our finding showed that the prepared chitosan based films, particularly $0.25 \%$ and $0.5 \%$ oil incorporated films, would provide an adequate level of moisture without any wound dehydration.

\subsection{Swelling degree}

Swelling property indicates the ability of wound dressing in absorption of wound fluids and exudates.The swelling ability of chitosan is important property for moisture environment and exudation of the wound site in skin regeneration and wound healing. The desirable and ideal value of swelling equilibrium degree for a wound dressing mainly depends on the type and condition of the wound [26]. Thus, the determination of water uptake of chitosan is important to improve the biological activity. Swelling degree of chitosan films and incorporated oil films were represented in Fig. 5. Results showed that water uptake of the oil loaded films slightly decreased with increased oil content from 176\% (chitosan control) 


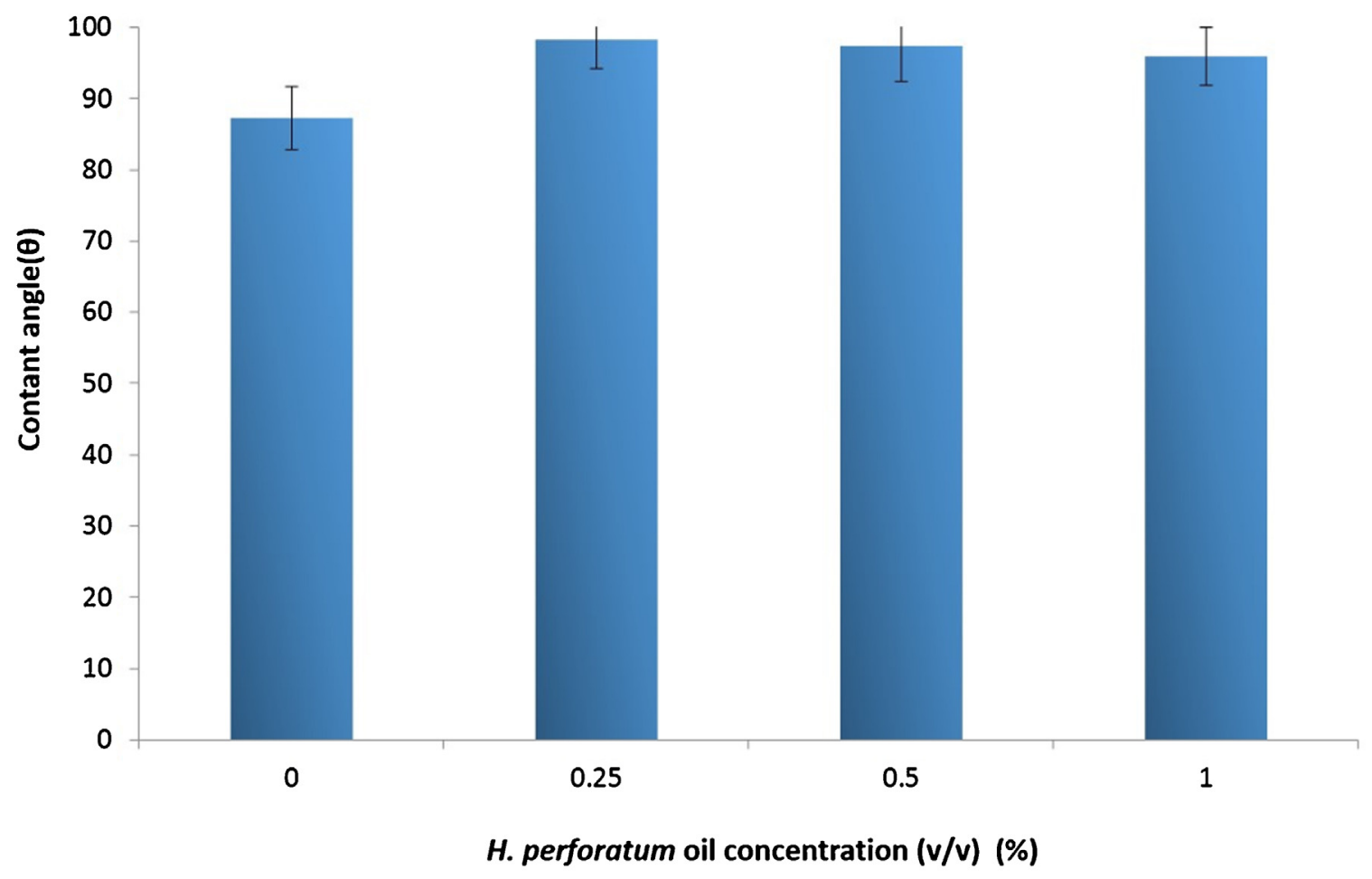

Fig. 6. Contact angle of pure and oil incorporated chitosan films.

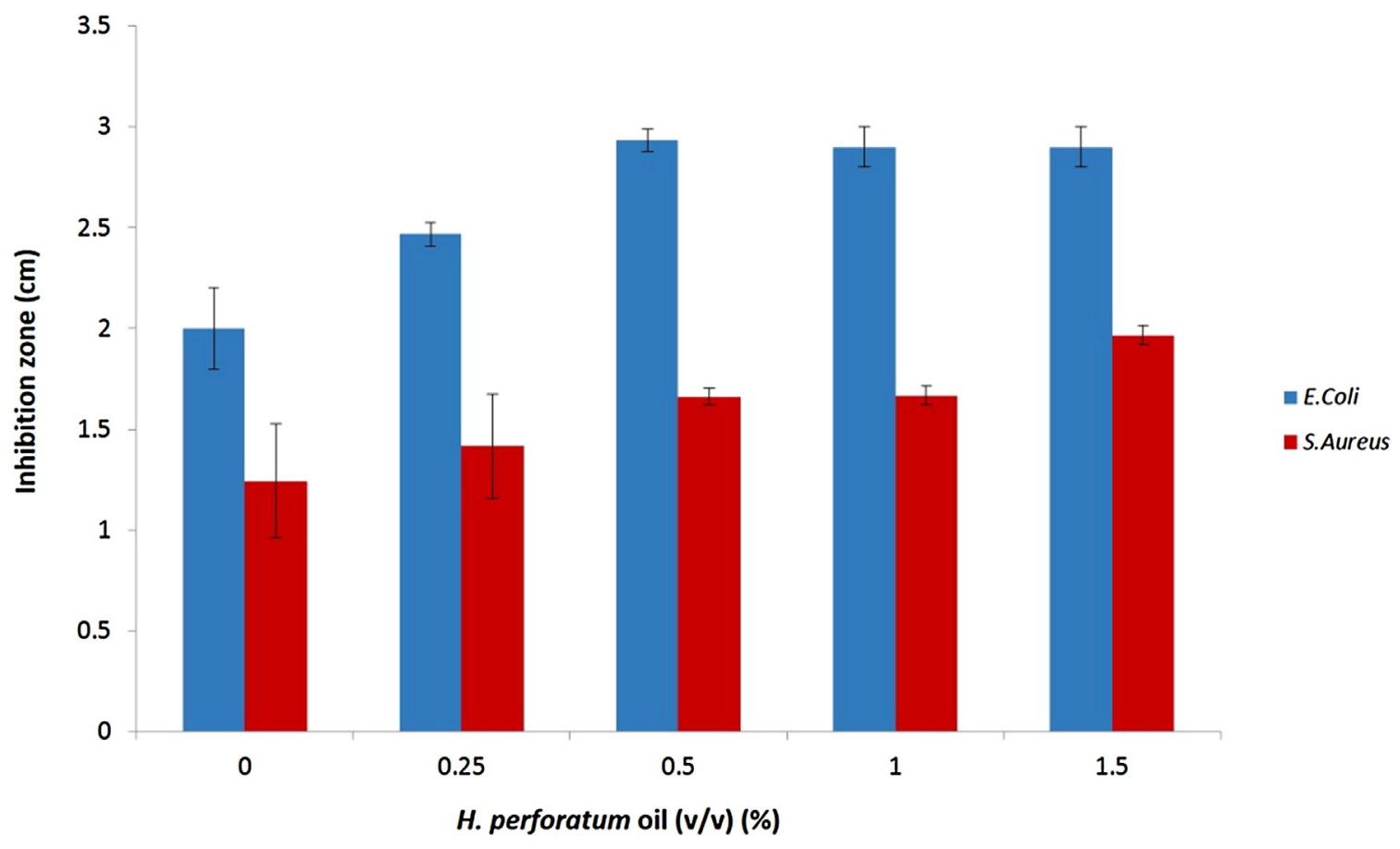

Fig. 7. Inhibition zone of chitosan based films.

to $115 \%$ ( $1 \%$ oil incorporated chitosan films) because of interaction between chitosan and oil. Due to hydrophobic nature of $\mathrm{H}$. perforatum oil, increased oil concentration causes an increase in film hydrophobicity. Since swelling of the film is related to the water diffusion, ionization of amino or carboxyl groups of polymer, decrease in swelling degree can be explained by increasing crosslinking interactions between chitosan and hydrophobic EOs as explained in the study of Peng and Li for chitosan-oil film for food preservation study [16]. However, swelling degree slightly increased for $1.5 \%$ oil loaded films. This could be explained by the formation of porous structure with the addition of oil into chitosan matrix as supported by SEM data.

\subsection{Contact angle}

The contact angle of a material provides information about the hydrophilicity of the tested material. The hydrophilicity is one of the most important property effecting the cytocompatibility of 


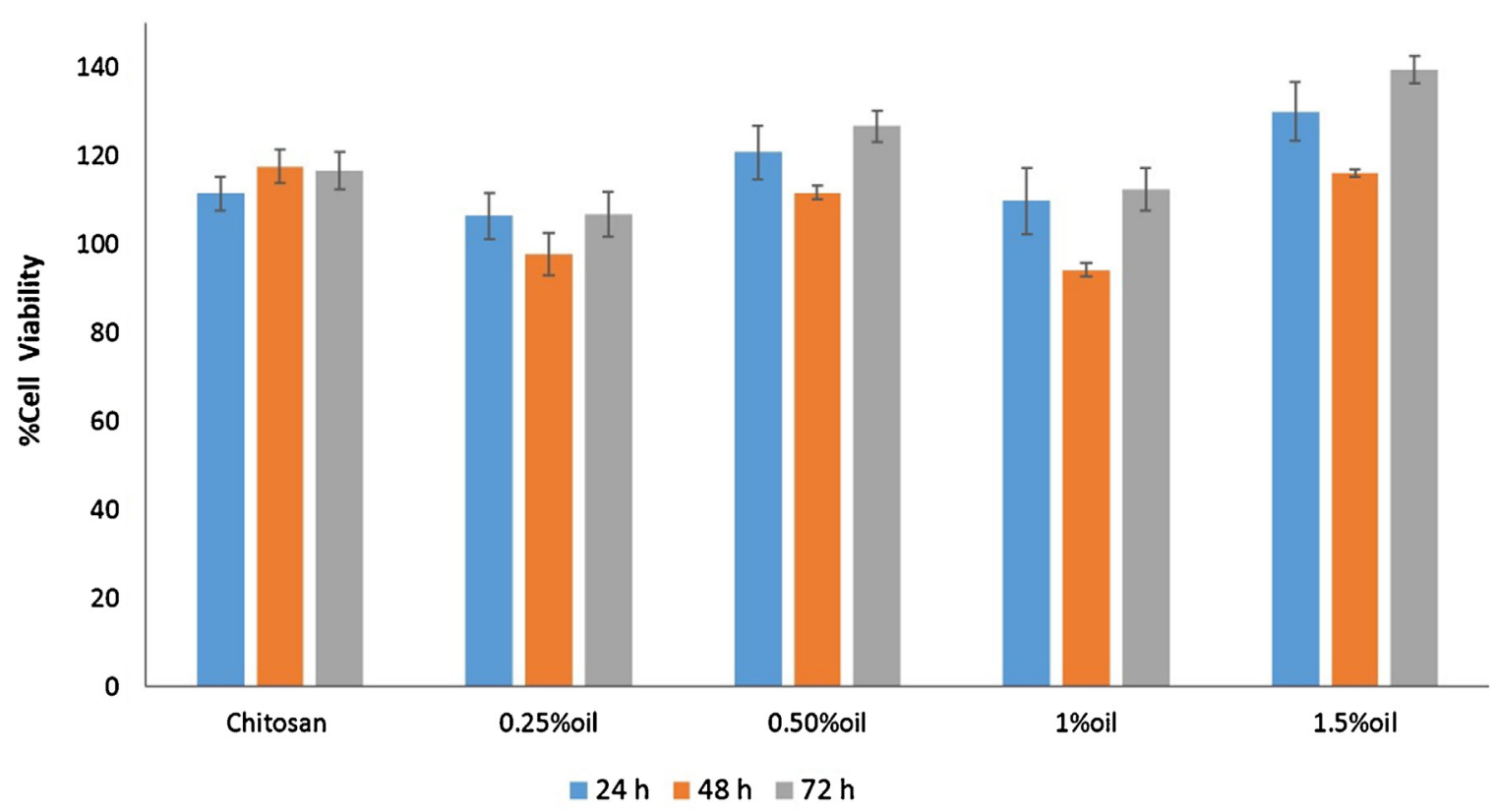

Fig. 8. In vitro cytotoxicity of pure and H. perforatum incorporated chitosan films.
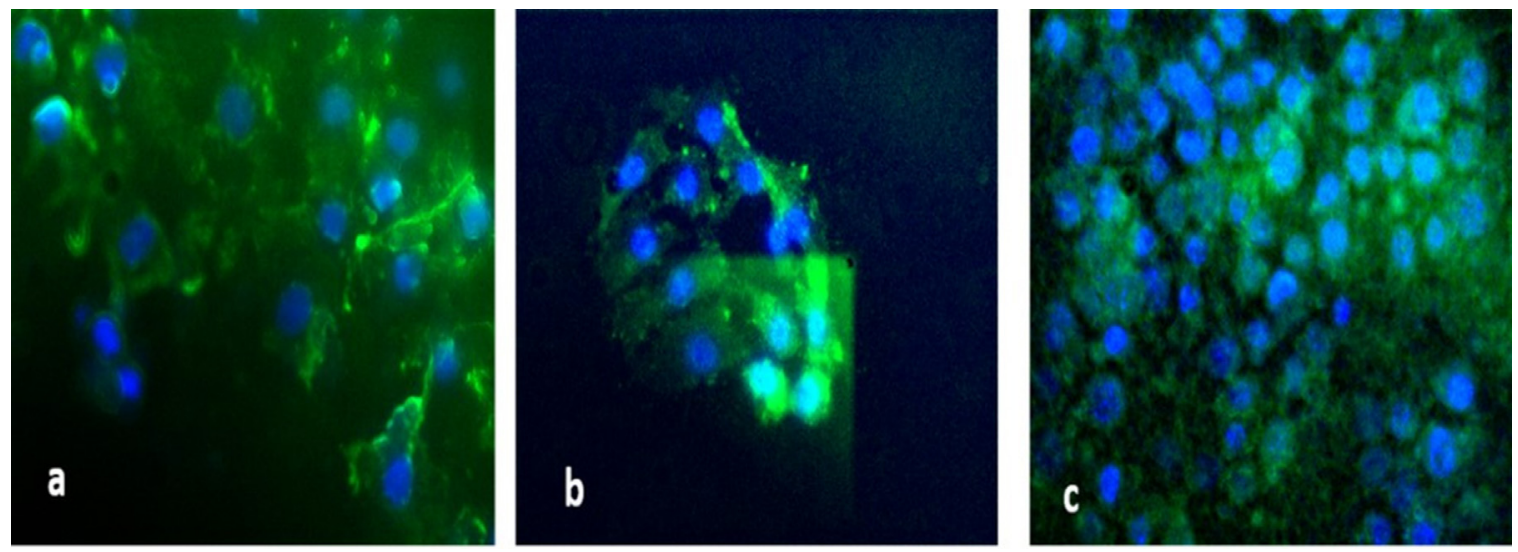

Fig. 9. Fluorescence imaging of cell attachment for (a) pure chitosan, (b) $0.25 \%$ oil and (c) $0.5 \%$ oil incorporated chitosan films after 3 days incubation.

biomaterials [27]. Since cells adhere and spread more effectively on surfaces with suitable hydrophilicity compared to hydrophobic surfaces [28]. However, the results in the literature showed that moderately wettable surfaces provides strong cell -subtrate and cel-cell interactions that induces better tissue regeneration [29]. In this study, the wettability of the prepared films was measured by the water contact angle test with using PBS droplets. The contact angle of the pure chitosan film was $87^{\circ}$. As the H. perporatum oil is incorporated into chitosan, the contact angle slightly increases upto $95-97^{\circ}$ due to the hydrophobic property of oil (Fig. 6). Contact angle values are found to be in good agreement with the swelling degree results.

\subsection{Antimicrobial activity}

Number of studies showed that chitosan is a potential carrier for antimicrobial agents which provides the delivery of antimicrobial agents to the infected tissue. Noel et al. evaluated a chitosan film as localized drug delivery device which does not require any surgery for removal due to the biodegradability of chitosan [30]. The antimicrobial activity of chitosan film incorporated with $\mathrm{H}$. perforatum oil was evaluated against Gram-negative bacterium, E.coli
Table 3

Antimicrobial activity of pure chitosan and oil incorporated chitosan $\operatorname{FFS}(n=3)$.

\begin{tabular}{lcc}
\hline $\begin{array}{l}\text { H. perforatum } \\
\text { concentration (\%) }\end{array}$ & S. aureus $(\mathrm{cm})$ & E. coli $(\mathrm{cm})$ \\
\hline 0 & $1.24 \pm 0.28$ & $2 \pm 0.2$ \\
0.25 & $1.42 \pm 0.26$ & $2.47 \pm 0.06$ \\
0.5 & $1.66 \pm 0.04$ & $2.93 \pm 0.06$ \\
1.0 & $1.67 \pm 0.05$ & $2.9 \pm 0.1$ \\
1.5 & $1.97 \pm 0.05$ & $2.9 \pm 0.1$ \\
\hline
\end{tabular}

and Gram-positive bacterium, S.aureus and results were presented in Table 3 and Fig. 7. The results showed that pure chitosan and oil incorporated chitosan films have antimicrobial activity on both test microorganisms. Antimicrobial activity increased with $\mathrm{H}$. perforatum oil concentration in chitosan matrix. It was found that E.coli bacteria is more sensitive to chitosan film incorporated with $\mathrm{H}$. perforatum oil than S. aureus bacteria. Essential oils destabilize and damage of phospholipid bilayer of cell membranes, enzyme systems and genetic material of bacteria [31]. Peng and Li reported that lemon, thyme, cinnamon oil and combinations incorporated in chitosan film solutions showed antimicrobial activity against $E$. coli and S. aureus [16]. They indicated that S. aureus was found more 

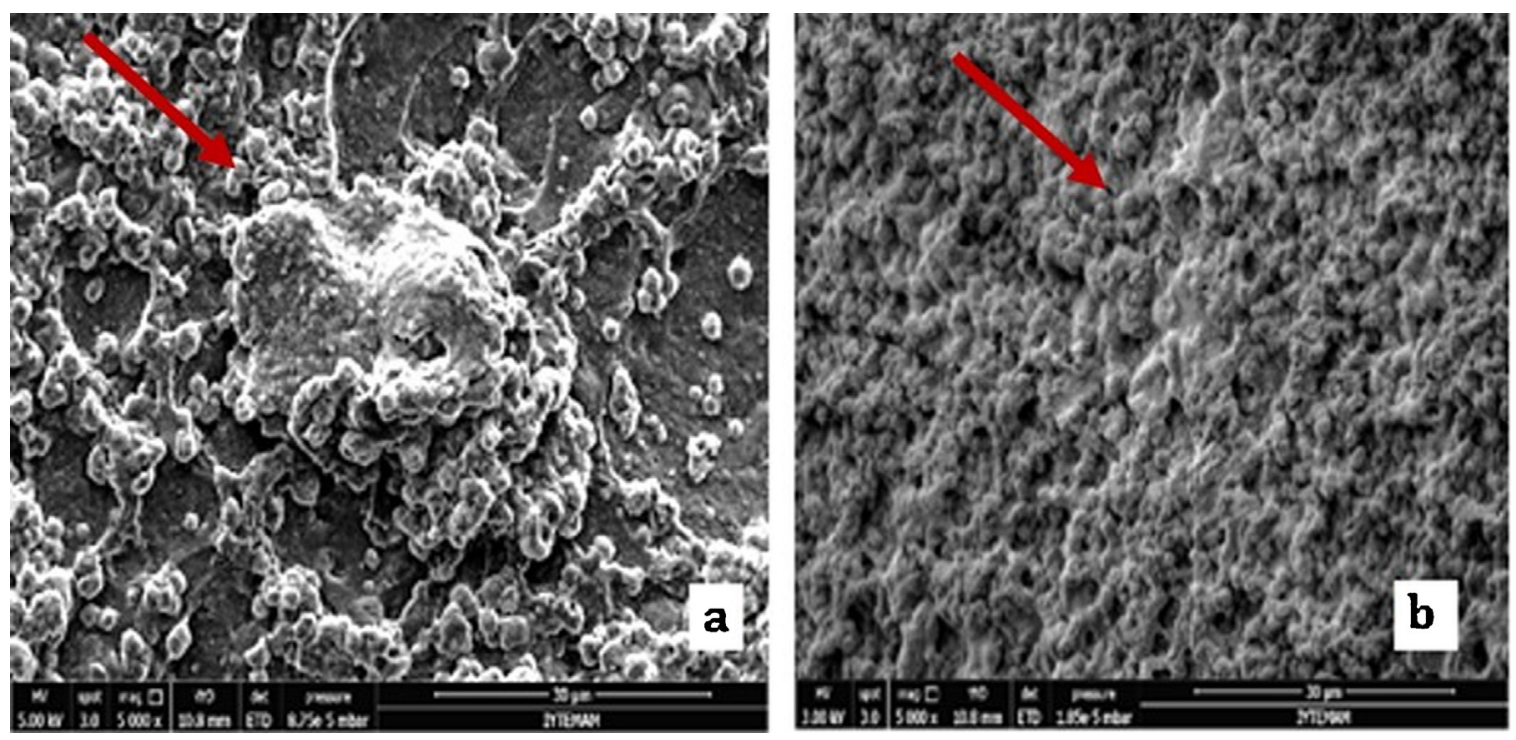

Fig. 10. SEM images of cell attachment on $0.25 \%$ oil (a) and $0.5 \%$ oil (b) incorporated chitosan films at the end of the 3 days incubation.

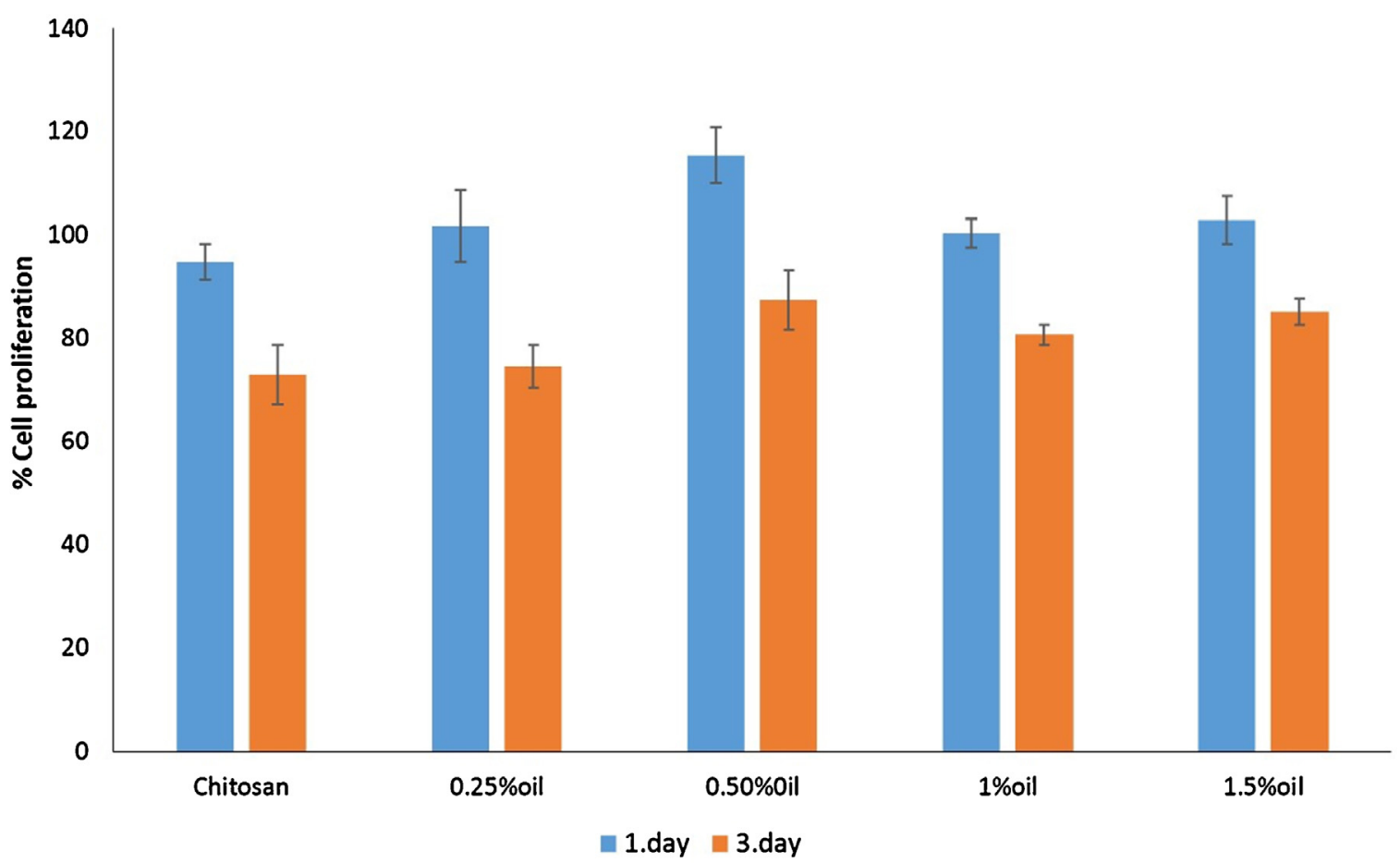

Fig. 11. In vitro cell attachment and proliferation on pure and $H$. perforatum incorporated chitosan films.

sensitive to film solutions than $E$. coli, due to the relatively impermeable outer membrane that surrounds Gram-negative bacteria whereas Altiok et al. showed that thyme oil incorporated chitosan films was more effective on E. coli [5].

It is known that chitosan damages bacterial cell membrane by increasing the permeability of the outer and inner membranes and thus leads to releasing the cellular content. This damage was caused by the electrostatic interaction between protonated amino groups of chitosan and phosphoryl groups of phospholipid components of cell membranes [32,33]. Incorporation of essential oils into chitosan films could improve the antimicrobial efficiency of the film due to the diffusion of the oil compounds would compensate the efficiency of chitosan. In addition, it was showed that EOs were more effective against Gram-positive bacteria than Gram-negative bacteria
[34]. The ideal local antibiotic system should provide more efficient delivery of higher levels of antibiotics to infection site in comparison to traditional methods and minimize the risks of systemic toxicity [30]. As a result chitosan film incorporated with $H$. perforatum oil is more resistant $E$. coli which is gram negative bacteria. These results prove that the $H$. perforatum oil could be incorporated in the chitosan film and inhibits target microorganisms

\subsection{In vitro cell viability}

In vitro cell viability of chitosan films was evaluated by using WST-1 assay according to indirect assay of ISO 10993-5. NIH3T3 fibroblast cell line was selected as model cell line because fibroblast cells are directly involved in the wound healing process and 
in the regeneration of cutaneous tissue [10]. Percentage viability of prepared films was presented in Fig. 8 for $24 \mathrm{~h}, 48 \mathrm{~h}$ and $72 \mathrm{~h}$ of incubation periods. NIH3T3 cell viability results indicated that both chitosan and oil loaded chitosan films did not show any cytotoxic effect. It was clear that all tested films exhibited high cell proliferation which indicates their high biocompability. In addition, oil loaded films showed proliferative effect on fibroblast cell line with high oil concentrations $(>0.25 \%$ ) compared to unloaded films.

\subsection{In vitro cell proliferation and attachment}

In vitro cell proliferation studies were performed 1 and 3 day incubation periods with NIH3T3 cell line. on prepared films were after 3 days incubation. Cells incubated on films for 3 days were stained with phalloidin and DAPI fluorescence stains and then cell attachment and proliferation were qualitatively examined by fluorescent microscopy. Fluorescence image results of the cells on chitosan films showed that cell-chitosan interaction and the live cells were stained with DAPI and phalloidin fluorescence on chitosan matrix (Fig. 9). It was also clear that cells were attached and onto the film surface successfully. Both chitosan and oil incorporated chitosan film served as good matrix for cell attachment and proliferation cells spread on composite scaffolds uniformly and attached on pore walls. SEM imaging results also confirmed that NIH3T3 cells attached to the oil loaded chitosan film surface (Fig. 10). Chitosan provides a good surface to grow, proliferate, and differentiate of fibroblast cells. NIH3T3 fibroblast cells had tendency to disperse and spread on oil incorporated chitosan surfaces. Fibroblasts are mesenchymal cells enable tissue maintenance and support by secreting extracellular matrix (ECM) in connective tissue. Therefore, fibroblasts are responsible for inducing inflammation and scar formation during wound healing [35]. Positive charge of chitosan promotes cell and protein adsorption so that acceleration the hemostasis of the wound by coalescing erythrocytes, forming a blood clot. Since the structure of chitosan is similar with hyaluronic acid of ECM [36], hence it enhances production of extracellular matrix during the wound healing process due to the hydrophilicity and similarity to ECM [4].

To quantify the cell attachment and proliferation of prepared films, WST-1 assay was used. Chitosan and oil incorporated chitosan films supported NIH3T3 fibroblast cell growth and showed proliferative effect, during three days of incubation (Fig. 11). These cell proliferation results on the fabricated films indicated good biocompatibility.

\section{Conclusion}

H. perforatum incorporated chitosan films were fabricated for potential wound dressing applications. In our study, the effects of $H$. perforatum oil incorporation into chitosan films on physical, antimicrobial and cell proliferation properties were investigated. $H$. perforatum has antimicrobial and antioxidant property mainly due to its flavonoid components. The antimicrobial test results demonstrated that all prepared films have antimicrobial activity on tested microorganisms used in the study. The WVP of chitosan film was increased by incorporating the essential oil to the films. $0.25 \%$ and $0.50 \%$ oil incorporated films were found to be more permeable than other films and suitable for providing an adequate level of moisture to the wound area. Prepared films showed high swelling property which could be used in moderate to highly exuding wounds. Water vapor permeability of the films increased, however, mechanical strength decreased with $H$. perforatum oil incorporation. Although tensile stress decreased with increasing oil content, about\%140 increase in strain of the films was achieved with $0.25 \%$ oil incorporated films. Furthermore, biocompatibility assay showed that non-cytotoxicity of the films on fibroblast cells. Additionally, chitosan provides a good matrix for cell proliferation as indicated in our cell attachment and proliferation results. The prepared films showed cell proliferative effect on NIH3T3 fibroblast cells. The combination of antibacterial effect and wound healing property makes chitosan based wound dressings an attractive solution for wound care management. The proposed biomaterial serves as a transdermal drug delivery wound dressing. These findings showed that the $H$. perforatum incorporated chitosan films could be used as a potential dressing biomaterial for promoting wound healing. Therefore, chitosan films with $H$. perforatum oil represent an innovative and novel bioactive dressing material in the wound care management market. However, further studies are required in order to investigate the effects of other factors on fibroblast response and cellular/tissue responses as well as wound healing models.

\section{References}

[1] W. Paul, C. Sharma, Chitosan and alginate wound dressings: a short review, Trends Biomater. Artif. Organs 18 (2004) 18-23 http://medind.nic.in/taa/t04/ i1/taat04i1p18.pdf.

[2] H.E. Thu, M.H. Zulfakar, S.F. Ng, Alginate based bilayer hydrocolloid films as potential slow-release modern wound dressing, Int. J. Pharm. 434 (2012) 375-383, http://dx.doi.org/10.1016/j.ijpharm.2012.05.044.

[3] H.V. Pawar, J. Tetteh, J.S. Boateng, Preparation, optimisation and characterisation of novel wound healing film dressings loaded with streptomycin and diclofenac, Colloids Surf. B Biointerfaces 102 (2013) 102-110, http://dx.doi.org/10.1016/j.colsurfb.2012.08.014.

[4] R. Jayakumar, M. Prabaharan, P.T. Sudheesh Kumar, S.V. Nair, H. Tamura, Biomaterials based on chitin and chitosan in wound dressing applications, Biotechnol. Adv. 29 (2011) 322-337, http://dx.doi.org/10.1016/j.biotechadv. 2011.01.005.

[5] D. Altiok, E. Altiok, F. Tihminlioglu, Physical, antibacterial and antioxidant properties of chitosan films incorporated with thyme oil for potential wound healing applications, J. Mater. Sci. Mater. Med. 21 (2010) 2227-2236, http:// dx.doi.org/10.1007/s10856-010-4065-x.

[6] A.D. Sezer, F. Hatipoğlu, E. Cevher, Z. Oğurtan, A.L. Baş, J. Akbuğa, Chitosan film containing fucoidan as a wound dressing for dermal burn healing: preparation and in vitro/in vivo evaluation, AAPS PharmSciTech 8 (2007), http://dx.doi.org/10.1208/pt0802039, Article 39.

[7] G. Gainza, S. Villullas, J.L. Pedraz, R.M. Hernandez, M. Igartua, Advances in drug delivery systems (DDSs) to release growth factors for wound healing and skin regeneration, Nanomed. Nanotechnol. Biol. Med. 11 (2015) 1551-1573, http://dx.doi.org/10.1016/j.nano.2015.03.002.

[8] R. Pereira, A. Carvalho, D.C. Vaz, M.H. Gil, A. Mendes, P. Bártolo, Development of novel alginate based hydrogel films for wound healing applications, Int. J. Biol. Macromol. 52 (2013) 221-230, http://dx.doi.org/10.1016/j.ijbiomac. 2012.09.031.

[9] I. Liakos, L. Rizzello, D.J. Scurr, P.P. Pompa, I.S. Bayer, A. Athanassiou, All-natural composite wound dressing films of essential oils encapsulated in sodium alginate with antimicrobial properties, Int. J. Pharm. 463 (2014) 137-145, http://dx.doi.org/10.1016/j.ijpharm.2013.10.046.

[10] I. Liakos, L. Rizzello, H. Hajiali, V. Brunetti, R. Carzino, P.P. Pompa, Fibrous wound dressings encapsulating essential oils as natural antimicrobial agents, J. Mater. Chem. B Mater. Biol. Med. 3 (2015) 1583-1589, http://dx.doi.org/10. 1039/C4TB01974A.

[11] M. Blumenthal, A.B. Council, Therapeutic Guide to Herbal Medicines, 1998, http://mfkp.org/INRMM/article/13578566\%5Cnhttp:/http://files/1760/ 13578566.html.

[12] K. Linde, B. Mm, L. Kriston, St John's wort for major depression (Review), Cochrane Database Syst. Rev. 4 (2008), http://dx.doi.org/10.1002/14651858. CD000448.pub3 www.cochranelibrary.com.

[13] Z. Saddiqe, I. Naeem, A. Maimoona, A review of the antibacterial activity of Hypericum perforatum L, J. Ethnopharmacol. 131 (2010) 511-521, http://dx. doi.org/10.1016/j.jep.2010.07.034.

[14] S. Kıyan, Y. Uyanikgil, A.Y. Altunci, Investigation of acute effects of hypericum perforatum (Kantaron) treatment in experimental thermal burns and comparison with silver sulfadiazine treatment, Turkish J. Trauma Emerg. Surg. 21 (2015) 323-336, http://dx.doi.org/10.5505/tjtes.2015.63822.

[15] A.I. Prisäcaru, C.V. Andrițoiu, C. Andriescu, E.C. Hăvârneanu, M. Popa, A.G.M. Motoc, A. Sava, Evaluation of the wound-healing effect of a novel Hypericum perforatum ointment in skin injury, Rom. J. Morphol. Embryol. 54 (2013) 1053-1059, 54041310531059 [pii]

[16] Y. Peng, Y. Li, Combined effects of two kinds of essential oils on physical, mechanical and structural properties of chitosan films, Food Hydrocoll. 36 (2014) 287-293, http://dx.doi.org/10.1016/j.foodhyd.2013.10.013.

[17] Y. Pranoto, V.M. Salokhe, S.K. Rakshit, Physical and antibacterial properties of alginate-based edible film incorporated with garlic oil, Food Res. Int. 38 (2005) 267-272, http://dx.doi.org/10.1016/j.foodres.2004.04.009. 
[18] A.F.D, S. Zivanovic, S. Chi, Antimicrobial activity of chitosan films enriched with essential oils, Science (80-.) 70 (2005) 45-51.

[19] M.A. Rojas-Graü, R.J. Avena-Bustillos, C. Olsen, M. Friedman, P.R. Henika, O Martín-Belloso, Z. Pan, T.H. McHugh, Effects of plant essential oils and oil compounds on mechanical, barrier and antimicrobial properties of alginate-apple puree edible films, J. Food Eng. 81 (2007) 634-641, http://dx. doi.org/10.1016/j.jfoodeng.2007.01.007.

[20] E.T.R, A. Cagri, Z. Ustunol, Antimicrobial, mechanical, and moisture barrier properties of low $\mathrm{pH}$ whey protein-based edible films containing p-aminobenzoic or sorbic acids, J. Food Sci. 66 (2001) 865-870, http://dx.doi. org/10.1111/j.1365-2621.2001.tb15188x.

[21] S.F. Hosseinia, M. Rezaeia, M. Zandib, F. Farahmandghavic, Bio-based composite edible films containing Origanum vulgare L. essential oil, Ind. Crops Prod. 67 (2015) 403-413.

[22] M. Abdollahi, M. Rezaei, G. Farzi, A novel active bionanocomposite film incorporating rosemary essential oil and nanoclay into chitosan, J. Food Eng. 111 (2012) 343-350, http://dx.doi.org/10.1016/j.jfoodeng.2012.02.012.

[23] L.O. Lamke, G.E. Nilsson, H.L. Reithner, The evaporative water loss from burns and the water-vapour permeability of grafts and artificial membranes used in the treatment of burns, Burns 3 (1977) 159-165, http://dx.doi.org/10.1016/ 0305-4179(77)90004-3.

[24] Y.M. Lee, S.S. Kim, M.H. Park, K.W. Song, Y.K. Sung, I.K. Kang, beta-Chitin-based wound dressing containing silver sulfurdiazine, J. Mater. Sci. Mater. Med. 11 (2000) 817-823, http://dx.doi.org/10.1023/A:1008961730929.

[25] P. Wu, A.C. Fisher, P.P. Foo, D. Queen, J.D.S. Gaylor, In vitro assessment of water vapour transmission of synthetic wound dressings, Biomaterials 16 (1995) 171-175, http://dx.doi.org/10.1016/0142-9612(95)92114-L.

[26] M. Kokabi, M. Sirousazar, Z.M. Hassan, PVA-clay nanocomposite hydrogels fo wound dressing, Eur. Polym. J. 43 (2007) 773-781, http://dx.doi.org/10.1016/ j.eurpolymj.2006.11.030.

[27] M.A. De Moraes, A.C.D. Rodas, O.Z. Higa, M.M. Beppu, Membranes of Biopolymer Blends for Wound Healing, 2008.
[28] M.P. Prabhakaran, J.R. Venugopal, T. Ter Chyan, L.B. Hai, C.K. Chan, A.Y. Lim, S. Ramakrishna, Electrospun biocomposite nanofibrous scaffolds for neural tissue engineering, Tissue Eng. Part A 14 (2008) 1787-1797, http://dx.doi.org 10.1089 /ten.tea.2007.0393.

[29] K.L. Menzies, L. Jones, The impact of contact angle on the biocompatibility of biomaterials, Optom. Vis. Sci. 87 (2010) 387-399, http://dx.doi.org/10.1097/ OPX.0b013e3181da863e.

[30] S.P. Noel, H. Courtney, J.D. Bumgardner, W.O. Haggard, Chitosan films: a potential local drug delivery system for antibiotics, Clin. Orthop. Relat. Res. 466 (2008) 1377-1382, http://dx.doi.org/10.1007/s11999-008-0228-1.

[31] E. Abdollahzadeh, M. Rezaei, H. Hosseini, Antibacterial activity of plant essential oils and extracts: the role of thyme essential oil, nisin, and their combination to control Listeria monocytogenes inoculated in minced fish meat, Food Control. 35 (2014) 177-183, http://dx.doi.org/10.1016/j.foodcont. 2013.07.004.

[32] M. Campos, L. Cordi, N. Darán, L. Mei, Antibacterial activity of chitosan solutions for wound dressing, Macromol. Symp. 245-246 (2006) 515-518, http://dx.doi.org/10.1002/masy.200651373.

[33] L. Sánchez-González, M. Cháfer, M. Hernández, A. Chiralt, C. González-Martínez, Antimicrobial activity of polysaccharide films containing essential oils, Food Control 22 (2011) 1302-1310, http://dx.doi.org/10.1016/j. foodcont.2011.02.004.

[34] S. Burt, Essential oils: their antibacterial properties and potential applications in foods - a review, Int. J. Food Microbiol. 94 (2004) 223-253, http://dx.doi. org/10.1016/j.ijfoodmicro.2004.03.022.

[35] A. Bakar, M. Hilmi, A.S. Halim, A. Hassan, C.K. Lim, K. Noorsal, In vitro characterization of a chitosan skin regenerating template as a scaffold for cells cultivation, Springerplus 2 (79) (2013) 1-9.

[36] V. Hamilton, Y. Yuan, D.A. Rigney, A.D. Puckett, J.L. Ong, Y. Yang, S.H. Elder, J.D. Bumgardner, Characterization of chitosan films and effects on fibroblast cell attachment and proliferation, J. Mater. Sci. Mater. Med. 17 (2006) 1373-1381, http://dx.doi.org/10.1007/s10856-006-0613-9. 